\title{
Contribution of Agroforestry Systems to Farmer Income in State Forest Areas: A Case Study of Parungpanjang, Indonesia
}

\author{
Desmiwati Desmiwati ${ }^{1}{ }^{*}$, Thomas Oni Veriasa ${ }^{2}$, Aam Aminah ${ }^{1}$, Anggi Dian Safitri ${ }^{1}$, Kresno Agus \\ Hendarto ${ }^{1}$, Tri Astuti Wisudayati ${ }^{1}$, Hasan Royani ${ }^{1}$, Kurniawati Hastuti Dewi ${ }^{3}$, Sandy Nur Ikfal \\ Raharjo ${ }^{3}$, Dian Ratna Sari ${ }^{3}$ \\ 1 Forest Tree Seed Technology Research and Development Center, Ministry of Environment and Forestry, \\ Bogor-Indonesia 16001 \\ 2 Center for Regional Systems Analysis Planning and Development (Crestpent/P4W), IPB University, Bogor- \\ Indonesia 16127. \\ 3 The Center for Political Studies, Indonesian Institute of Science \\ *Corresponding author: desmiwati.wong@gmail.com; Tel: +62-813-810-94360
}

\begin{abstract}
Agroforestry activities in Forest Areas with Special Purpose (FASP) have been implemented since 2000 in Parungpanjang, West Java, which was subsequently reinforced by the Decree of the Minister of Environment and Forestry concerning the Recognition and Protection of Forest Partnerships (Kulin KK) for the Harapan Sejahtera and Guna Bakti Forest Farmer Groups in 2019. This study investigates the contribution of agroforestry systems to farmer income using a household survey in the Parungpanjang Research Forest. The study aims to analyze: 1) the contribution of agroforestry to farmer income from a household structured income analysis; 2) factors of agroforestry that influence total farmer household income using multiple regression analysis. The results show that agroforestry systems contributed $15.8 \%$ to farmer household income. The highest agroforestry productivity occurs in the age group of 41-45 years with an average of managed land area of 0.65 hectares and average annual income of IDR 16,780,000 (USD 1,198.6)/farmer/year. The statistical model showed that agroforestry income does not have a significant influence on total farmer household income due to differences in the types of commercial crops, motivation, and skill, as well as age related to physical abilities. There are only two agroforestry factors, namely age and land area, that have a significant influence on total farmer income, whereby the direction of the age variable has a negative influence.
\end{abstract}

Keywords: Agroforestry systems; Household income; Research Forest; Social forestry

\section{Introduction}

In order to address the global challenges of climate change, food security, and rural poverty, changes in environmental management systems are required. In the forestry sector, agroforestry is increasingly recognized as a viable option for overcoming these challenges (Mutonyi \& Fungo, 2011). Agroforestry is a system of natural resources management that integrates trees on farms and in the agricultural landscape to diversify and sustain production (Molla, 2019). Agroforestry is a costeffective strategy for climate change mitigation (Baliton et al., 2017), that provides benefits on carbon sequestration and storage (Zomer et al., 2016; Feliciano et al., 2018), increases ecosystem services (Shin et al., 2020), simultaneously provides job opportunities (Borrella et al., 2015), and there is a positive relation between agroforestry and community (Humphries et al., 2012).

In practice, agroforestry is often described as a suitable system for the needs of community in their land use systems. Several studies of agroforestry systems in Indonesia have shown that it has brought about several positive impacts particularly because it increases productivity of forest land (Suryanto et al., 2013), improves soil quality (Mulyono et al., 2019), plays an important role in maintaining avian diversity (Withaningsih et al., 2020), brings economic benefits for local communities (Sudaryanto \& Variasa, 2018; Kamaluddin et al., 2020), and promotes food security 
(Wulandari et al., 2014). However, agroforestry still faces challenges mainly with regard to the agriculture expansion caused by commercialization of timber (Kusters et al., 2008), poverty alleviation and farmer household welfare (Nuryati et al., 2019), community participation (Dwijanti et al., 2018), and lack of market and community access to finance opportunities (Suyadi et al., 2019).

To date, the Government of Indonesia has established 35 Forest Areas with Special Purpose (FASP) for research, education, training and religious purposes. FASPs are located in various regions with a total area of 37,569.05 hectares (Ratina, 2019), one of which is located in Parungpanjang, Bogor Regency, West Java. FASP Parungpanjang has applied agroforestry systems since 2016, which was subsequently received strengthened authority by forestry partnerships through the Social Forestry (SF) model since 2019. The SF provides access for Harapan Sejahtera and Guna Bakti Forest Farmer Groups (FFG) to manage the forest through an agrosilviculture model for 35 years. It is aimed at increasing the productivity of research on forest land, such as the quality of shade tree plants, the productivity of intercropping plants, soil fertility, and on the improvement of local community welfare (Desmiwati et al, 2018).

As a research forest, various studies on FASP Parungpanjang have already been carried out, particularly focusing on the technical aspects of silvicutural forest plants. Studies on the social economic aspects of the FASP, on the other hand, are still very limited and mostly conductive through qualitative research such as research on community attitudes and behavior (Surati, 2014), perceptions and participation levels of smallholder farmers (Desmiwati, 2016), social capital of smallholder farmers (Desmiwati et al, 2018), agroforestry patterns and livelihood strategies of smallholder farmers (Desmiwati \& Nugraheni, 2018) and economic perceptions of smallholder farmers (Hendarto et al, 2020), and roles and voice of farmers in the "special purpose" forest area: strengthening gender responsive policy (Dewi et al, 2020).

Referring to the aims of the agroforestry system and SF implementation in FASP Parungpanjang, this study aims to fill the gap on socio-economic aspects of FASP to complement the baseline data for impact measurement. The objectives of this study are as follows: first, to calculate the contribution of agroforestry to farmer income, and second, to analyze agroforestry factors that influence farmer income. The main research question of the study is: does agroforestry has a significant contribution to the rural economy?

\section{Methods}

\subsection{Study Area}

This study was conducted in the Parungpanjang FASP $\left(106^{\circ} 31^{\prime} 06^{\prime \prime} \mathrm{E}, 06^{\circ} 22^{\prime} 58,9^{\prime \prime} \mathrm{S}\right)$ managed by the Forest Tree Seed Technology Research and Development Center (FTSTRDC), of the Ministry of Environment and Forestry (MoEF). The area directly borders four villages namely Jagabaya and Gintung Cileujet Village, Parungpanjang District, and Tapos and Batok Village, Tenjo District, Bogor Regency, West Java (Figure 1). Initially, the Parungpanjang FASP was located in the Perum Perhutani production forest area as stated in the Loan and Use Agreement ${ }^{1}$. Subsequently, the designation was changed to a FASP in accordance with the Decree of the Minister of Environment and Forestry in 2019². Furthermore, on 27 August 2019, the Parungpanjang FASP became the first Social Forestry model implemented by the MoEF out of a total of 35 FASPs in Indonesia. The Social Forestry permit (35 years) is stipulated through the Decree of the Minister of Environment and Forestry Number SK. 7087/Menlhk-PSKL/PKPS/PSL.0/8/2019 concerning the Recognition and Protection of the Forest

\footnotetext{
${ }^{1}$ The Loan and Use Agreement No.08/044-3/III/1996 and 796/VIII-BTP/12/1996

2 The Decree of the Minister of Environment and Forestry No. SK.169/Menlhk/Setjen/PLA.0/2/2019 dated February 25, 2019 with an area of $\pm 100 \mathrm{Ha}$.
} 
Partnership (Kulin KK) of the Harapan Sejahtera Forest Farmer Group (FFG) covering an area of 10.7 hectares, which includes 19 members.

On the same date, MoEF also issued the Decree of the Minister of Environment and Forestry Number SK.7089/Menlhk-PSKL/PKPS/PSL.0/8/2019 concerning the Recognition and Protection of the Forest Partnership (Kulin KK) of Guna Bakti FFG covering an area of 8.75 hectares with 21 members.

This research provides a baseline of socio-economic data as a parameter to measure forest management using the Forestry Partnership scheme (Kulin KK).

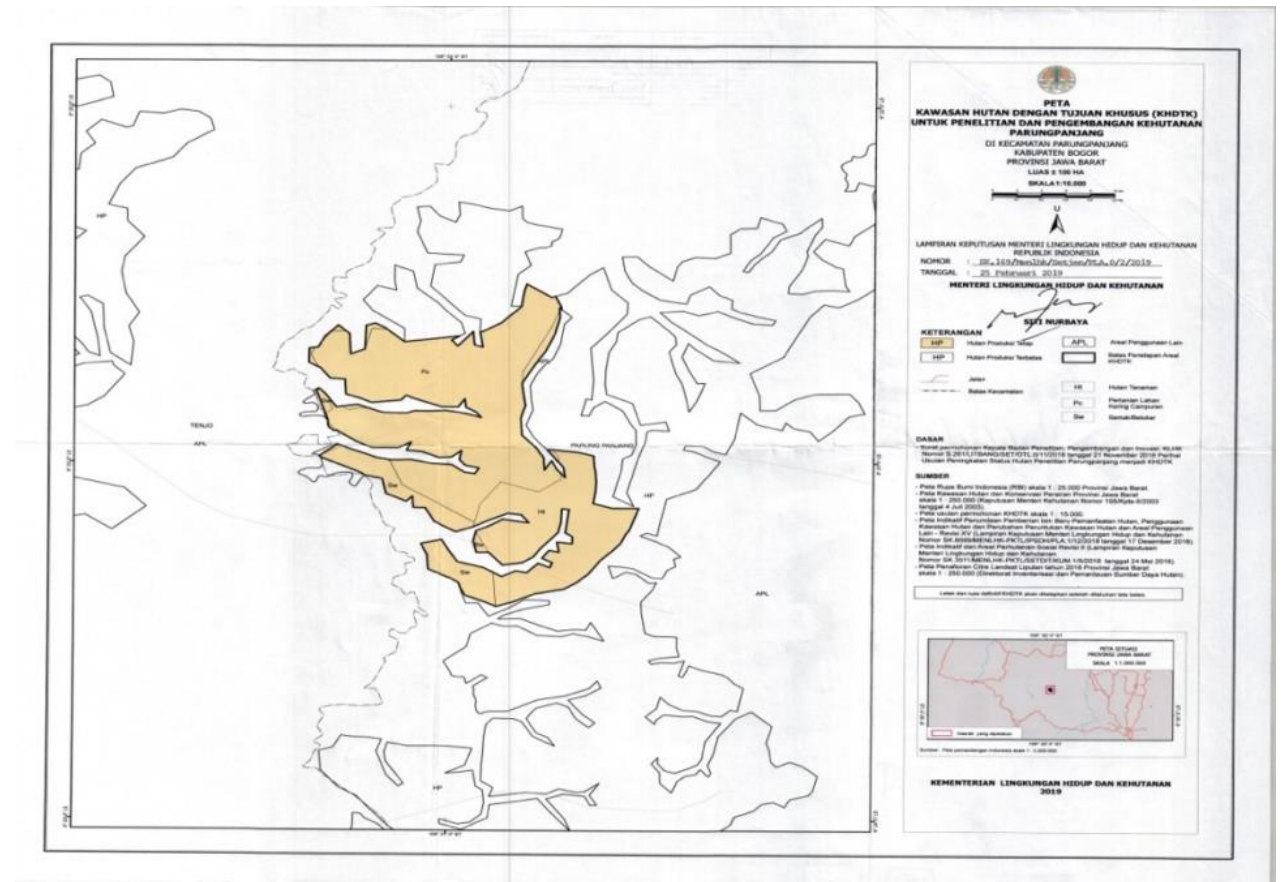

Figure 1. Location of field study

\subsection{Data Collection}

The data was collected from September until October 2019 using a household census survey with a total of 52 respondents consisting of farmer households in the Tapos Village $(\mathrm{N}=31)$ and Jagabaya Village $(\mathrm{N}=21)$, Bogor Regency, West Java. The household questionnaires drew from the National Survey on Socio-economic Issues questionnaire developed by the Indonesia Bureau of Statistics (BPS), and introduced several modifications. The census method and questionnaire was used to explore the demographic characteristics of the village and the respondents, as well as collecting baseline data for further in-depth surveys (Malleson et al., 2008). Meanwhile, observations and in-depth interviews were conducted to obtain detailed farmer household socioeconomic dynamics and demographic information.

Furthermore, two focus group discussions (FGD) were conducted in each village with 25 farmer participants in Tapos Village and 21 participants in Jagabaya Village. The FGDs verified and deepened information related to agroforestry patterns and types of commercial crops that had been developed, as well as information on seasonal calendars and agroforestry income referring to each type of commercial crops cultivated.

\subsection{Analysis}

2.3.1 Contribution of agroforestry income to total farmer household income 
Total farmer income was analyzed by calculating all activities that generate both cash and inkind income. In-kind income is calculated by summing up all the value of products consumed directly by farmer households (Faße \& Grote, 2013; Angelsen et al., 2014). The formula used is as follows:

Total farmers income $=\Sigma$ (On-farm Income + Off-farm income+Non-farm Income)

In this study, on-farm income activities included agroforestry and livestock, and off-farm income included work as daily laborers. Non-farm income activities included stalls and hawkers, bike mechanics, craftmans (Boboko/bamboo craft) and others (service activities and transfers). The agroforestry contribution was analyzed by calculating agroforestry income to the total farmers income in a year. The formula used is as follows:

$$
\% \operatorname{Igri}=\left(\frac{\mathrm{Igr}}{\mathrm{I} \text { tot }}\right) \times 100 \%
$$

Where, $\%$ Igri = Contribution of agroforestry income to the total farmers income (\% in a year); Igr = total income from agroforestry activities (IDR/year); Itot = Total farmers income (IDR/year).

\subsubsection{Factors of agroforestry system that influence farmer household income}

Multiple linear regression analysis was carried out to determine agroforestry factors that have a significant influence on farmer income. The equation model (Sarstedt \& Mooi, 2014) is as follows:

$$
\mathrm{Y}=\alpha+\beta_{1} \mathrm{X}_{1}+\beta_{2} \mathrm{X}_{2}+\beta_{3} \mathrm{X}_{3}+\beta_{4} \mathrm{X}_{4}+\beta_{5} \mathrm{X}_{5}+e
$$

Where, $Y=$ Farmers income (IDR/year); $\alpha=$ constant; $\beta_{1-} \beta_{8}=$ regression coefficient; $X_{1}=$ Agroforestry income (IDR/year); $X_{2}=$ Age (years); $X_{3}=$ Education (years); $X_{4}=$ Family size (person); $X_{5}=$ Land area (hectare); $e=$ error. The $t$ test is conducted by comparing the $p$-value (Sig.) of the regression test results with the degree of error used in this model i.e. $10 \%$ or $\alpha=0.1$. The references of variables can be seen in Table 1 below.

Table 1. References of Variables

\begin{tabular}{lll}
\hline No & Variable & Source of References \\
\hline 1. & Age & Suherdi et al., 2014 \\
2 & Education & Marschke \& Berkes, 2005; Parhusip et al., 2019 \\
3 & Family size & Rahman et al., 2017 \\
4 & Land area & Nyaga et al., 2015, Van Chu et al., 2019 \\
\hline
\end{tabular}

Due to data limitations (52 farming households), this research conducted several tests on the regression model to mitigate statistical issues that might arise and ensure the robustness of the model i.e Normality, Linearity, Heteroscedasticity, Multicollinearity and Regression Spesification Error Test (RESET).

\section{Results and Discussions}

\subsection{Agroforestry practice}

The main tree species that dominate the forest vegetation structure of the Parungpanjang FASP are mahogany (Swietenia macrophylla), acacia (Acacia mangium), nyamplung (Calophyllum inophilum), gempol (Nauclea orientalis i Linn), merbau (Intsia bijuga), kepuh (Sterculia foetida), mindi (Melia azedarach), tisuk (Hibiscus sp) and white jabon (Anthocephalus cadamba). Intercropped plants were dominted by galangal (Lenguas galangal), chinese potato (Coleus 
tuberosus) and peanut (Arachis hypogaea). Tree plantations in this area are research objects of FTSTRDC.

Farmer Groups members in Tapos Village and Jagabaya Village have practiced agro-silviculture by applying alley-cropping techniques in a simple pattern with a limited number of intercropping cultivated varieties. Alley-cropping techniques allow farmers to plant agricultural crops in alleys in between woody plants (Shin et al., 2020). The main inter-cropped plant species was galangal (Lenguas galanga) with other secondary and additional intercropped plants (Table 2).

Table 2. Agroforestry patterns adopted by farmers in FASP Parungpanjang.

\begin{tabular}{cllc}
\hline Agroforestry & \multicolumn{3}{c}{ Intercropped plants } \\
\cline { 2 - 4 } Patterns & \multicolumn{1}{c}{ Primary } & \multicolumn{1}{c}{ Secondary } & Additional \\
\hline Type 1 & Galangal (Lenguas galanga) & Pongamia (Pongamia pinnata) & \\
Type 2 & Galangal (Lenguas galanga) & Largeleaf rosemallow (Hibiscus macrophyllus) & \\
Type 3 & Galangal (Lenguas galanga) & Peanut (Arachis hypogaea) & utilissima) \\
Type 4 & Galangal (Lenguas galanga) & Chinese potato (Coleus tuberosus) & Banana (Musa sp.) \\
Type 5 & Galangal (Lenguas galanga) & Red Jabon (Anthocephalus macrophyllus) & \\
Type 6 & Galangal (Lenguas galanga) & Cheesewood (Nauclea orientalis) & \\
\hline
\end{tabular}

Source: Primary data, 2019

\subsection{Contribution of agroforestry to farmer income}

Table 3. shows the education level of the respondents in both villages. The majority of the respondents graduated from elementary school (55.8\%), while $36.6 \%$ did not graduate from elementary school, although most of them can read and write. Only $7.6 \%$, or four respondents, had a higher education level than other respondents. According to age group, respondents over 45 years old amounted to $67.3 \%$, while $13.4 \%$ of respondents were over 60 years old (Table 4 ).

The study found that the age of respondents ranged from 30-78 years. Table 4 shows that the age group of $41-45$ years (9.6\%) managed the largest part of agroforestry land area than other age groups, namely an average of 0.65 hectares. Out of the total land managed by farmers $(22.9$ hectares), the average area of managed land is 0.44 hectares per farmer.

Table 3. Education level of farmers

\begin{tabular}{|c|c|c|c|}
\hline No & Education level & Frequency & Percentage \\
\hline 1 & Did not graduate from Elementary School ( $<6$ years) & 19 & 36.6 \\
\hline 2 & Elementary School - SD (6 years) & 29 & 55.8 \\
\hline 3 & Junior High School - SMP (9 years) & 2 & 3.8 \\
\hline \multirow[t]{2}{*}{4} & Senior High School - SMA (12 years) & 2 & 3.8 \\
\hline & Total & 52 & 100 \\
\hline
\end{tabular}

Source: Primary data, 2019; $\mathrm{N}=52$

Table 4. Farmer composition based on age group

\begin{tabular}{ccccc}
\hline Age Group & \multicolumn{2}{c}{ Farmers Households } & $\begin{array}{c}\text { Total Land Area } \\
\text { (Hectare) }\end{array}$ & $\begin{array}{c}\text { Land Area per age } \\
\text { group (hectare) }\end{array}$ \\
\cline { 2 - 3 } & $\mathrm{N}$ & Percentage & 1.25 & 0.31 \\
$30-35$ & 4 & 7.7 & 2.90 & 0.36 \\
$36-40$ & 8 & 15.4 & 3.25 & 0.65 \\
$41-45$ & 5 & 9.6 & 7.00 & 0.47 \\
$46-50$ & 15 & 28.9 & 3.00 & 0.50 \\
$51-55$ & 6 & 11.5 & 3.25 & 0.46 \\
$56-60$ & 7 & 13.5 & 1.00 & 0.33 \\
$61-65$ & 3 & 5.7 & 1.25 & 0.31 \\
$>65$ & 4 & 7.7 & 22.9 & 0.44 \\
\hline
\end{tabular}

Source: Primary data, 2019 
Table 5 shows that the contribution of agroforestry income to total farmer income was $15.8 \%$ with an average agroforestry income of IDR 3,829,519 (US\$273.5) per farmer per year. The highest contribution to total farmer income was from working as daily laborers (33.7\%), followed by income from stall/hawkers (28.9\%). The lowest contribution to farmer income is from livestock (1.6\%). Agroforestry is an alternative livelihood option where the main income of farmers are off-farm and non-farm activities. This is because farmer households are landless and are unable to develop agricultural activities. Furthermore, low education and poverty have caused them to seek out selected employment that relies more on physical abilities that do not require large capital, such as daily laborers and hawkers.

Table 5. Average farmer household income based on income sources per year (in IDR)

\begin{tabular}{|c|c|c|c|c|c|}
\hline No & Source of Income & Total Income & Mean & SD & Income Shared (\%) \\
\hline \multirow[t]{3}{*}{1} & On-farm & & & & \\
\hline & Agroforestry & $199,135,000$ & $3,829,519$ & $6,255,682$ & 15.8 \\
\hline & Livestock & $20,800,000$ & 400,000 & $1,670,505$ & 1.6 \\
\hline \multirow[t]{2}{*}{2} & Off-farm & & & & \\
\hline & Daily laborers & $424,990,000$ & $8,172,885$ & $13,440,567$ & 33.7 \\
\hline \multirow[t]{6}{*}{3} & Non-farm & & & & \\
\hline & Stall/Hawkers & $364,565,000$ & $7,010,865$ & $14,345,205$ & 28.9 \\
\hline & Bike Mechanic & $28,800,000$ & 553,846 & $3,993,841$ & 2.3 \\
\hline & Craft (Boboko) & $42,386,500$ & 815,125 & $2,328,566$ & 3.4 \\
\hline & Others & $180,080,000$ & $3,463,076$ & $6,646,217$ & 14.3 \\
\hline & Total & $1,260,756,500$ & $24,245,316$ & $17,743,668$ & 100 \\
\hline
\end{tabular}

Source: Primary Data, 2019 Total N= 52; US\$1= IDR 14,000

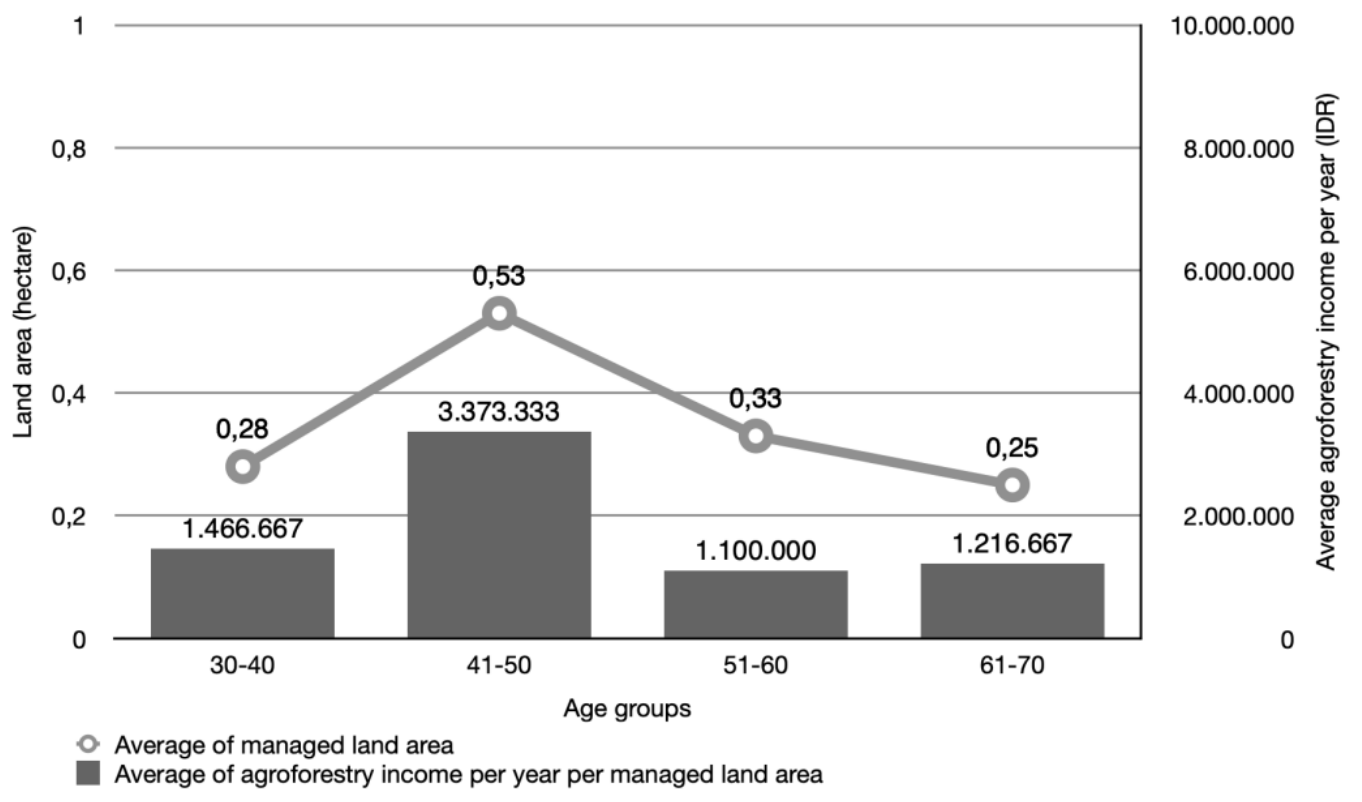

Figure 2. Distribution of farmer income based on land area and age group.

Figure 2 explains that the highest productivity of agroforestry occurs in farmers aged 41-45 years with an average land area of 0.65 hectares and an average income of IDR 16,780,000 (US\$1,198.6) per year per farmer. In the age group 46-50 and above, agroforestry income tends to decrease along with the area of land being managed. The downward trend of farmer income from agroforestry was explained in Table 2 and shows that the majority of farmer groups members involved in agroforestry businesses are over 45 years (67.3\%). 
While the age group of 30-40 years manages land with an average area of 0.31-0.36 hectares, yet, the level of agroforestry income is still relatively low in this group compared to the same level of land in other older age groups (61-65 years). This is due to the fact that younger farmers are not as focused on agroforestry, as it is viewed as an additional livelihood that makes the land become unproductive. The younger farmers earn their main income from other livelihood options such as daily laborers and hawkers.

In the case of the Parungpanjang FASP, the contribution of agroforestry income to total farmer household income is $15.8 \%$, with agroforestry income contribution in each farmer household described in Figure 2. This has been caused by the following 1) different types of intercropping planted, namely although the main intercropped plants (galangal) are relatively the same and provide a large share of income, yet other intercropped plants also contribute to increasing farmers income; 2) farmers motivation and skills, for farmers who regularly apply fertilizer and clean the land, the results are much better than plants that remain unmanaged after planting; 3 ) age also affects the physical ability to cultivate land. The majority of farmer groups members are already elderly and expressed that they are unable to cultivate larger areas land. These farmers feel that the land that has been cultivated is sufficient.

According to Brown et al. (2018), there are two important factors as a precondition for success in adopting an agroforestry system before making further interventions namely, successful mobilization and engagement of farmers and facilitating farmer capacity development and/or access to qualified tree/agriculture seeds. Several interventions are needed after the precondition phases have been met, include providing incentives, facilitating market networks, and institutional and policy change.

\subsection{Factors of agroforestry system that influence on the farmers household income}

The agroforestry system factors analyzed in this regression model are explained in Table 6. Of the five variables analyzed by t-test, there are two variables that have a significant influence on total farmer income, namely age and land area (Table 7), whereas education, family size, and agroforestry income variables do not have a significant influence on the total farmers household income.

Table 6. Explanation and summary statistics of variables

\begin{tabular}{llc|cc}
\hline \multicolumn{1}{c}{ Variable } & \multicolumn{1}{c}{ Explanation } & Mean & Std. Deviation & $\mathrm{N}$ \\
\hline Farmers Income $(\mathrm{Y})$ & $\begin{array}{l}\text { Total farmer income in IDR } \\
\text { per year }\end{array}$ & 24245317.31 & 17743668.217 & 52 \\
\hline Age $\left(\mathrm{X}_{1}\right)$ & Age in years & 50.2885 & 10.55580 & 52 \\
\hline Education $\left(\mathrm{X}_{2}\right)$ & Education in years & 4.6923 & 2.96739 & 52 \\
\hline Family Size $\left(\mathrm{X}_{3}\right)$ & $\begin{array}{l}\text { The family member of } \\
\text { household (person) }\end{array}$ & 3.5000 & 1.83110 & 52 \\
\hline Agroforestry Income $\left(\mathrm{X}_{4}\right)$ & $\begin{array}{l}\text { Household annual income } \\
\text { from agroforestry in IDR }\end{array}$ & 3817980.7692 & 6260676.86152 & 52 \\
\hline Land Area $\left(\mathrm{X}_{5}\right)$ & Land area in hectare & .4404 & .29952 & 52 \\
\hline Source: & &
\end{tabular}

Source: Primary data, 2019.

Age (Sig. 0.007) has a negative influence direction, which means that as age increases, farmer income will decrease, due to the contribution of agroforestry income also decreasing as farmers get older and the limited area of land that can be managed. Agroforestry activities require farmers who are in the productive age (18-50 years) due to intensive workload (Suherdi et al., 2014; Suyadi et al., 2019). In the Parungpanjang FASP context, farmer physical ability to manage land will determine the productivity and income received by the farmers. This phenomenon is verified by the findings listed in Figure 2. 
Table 7. Result of t-test

\begin{tabular}{lccccc}
\hline & \multicolumn{2}{c}{ Standardized Coefficients } & & & \multicolumn{2}{c}{ Collinearity Statistics } \\
\cline { 2 - 3 } Model & Beta & $\mathrm{t}$ & Sig. & Tolerance & VIF \\
\hline (Constant) & & 3.250 & .002 & & \\
Age $\left(\mathrm{X}_{1}\right)$ & -.400 & -2.814 & $.007^{*}$ & .816 & 1.226 \\
Education $\left(\mathrm{X}_{2}\right)$ & -.051 & -.364 & .718 & .827 & 1.209 \\
Family Size $\left(\mathrm{X}_{3}\right)$ & -.049 & -.369 & .713 & .926 & 1.080 \\
Agroforestry Income $\left(\mathrm{X}_{4}\right)$ & .035 & .251 & .803 & .849 & 1.178 \\
Land Area $\left(\mathrm{X}_{5}\right)$ & .282 & 2.041 &. $\mathbf{0 4 7 *}$ & .866 & 1.155 \\
\hline
\end{tabular}

a. Dependent Variable: $Y-$ Household Income; ${ }^{*}$ sigficant at $p$ value $<0.05$

Land area (Sig. 0.047) of the agroforestry system has a significant influence on the total farmer income. This is consistent with Van Chu et al. (2019), which stated that farmers with larger forestry land area have more chance to increase their household income. In this case, significant agroforestry income is obtained from farmers aged $41-45$ years with an average land area of 0.65 hectares. Land productivity is also closely related to farmer capacity and access to resources, as well as access to markets (Borrella et al., 2015; Brown et al., 2018).

\section{Conclusion}

Agroforestry practices in the Parungpanjang FASP have contributed to the income of farmer groups members, but the effects are still imbalanced. This is influenced by the types of plant cultivated, motivation and skills, and age relative to ability to manage land. Regarding the results of the regression analysis, there are two agroforestry factors that influence farmer income, namely age and land area.

In order to optimize the contribution of the agroforestry system to farmer income in the Parungpanjang FASP, it is necessary to increase land productivity by assessing profitable intercropped plant types in corresponding soil or land characteristics and minimum requirements of physical treatments. Furthermore, FTSTRDC need to strengthen the capacity of farmer groups members by facilitating technical capacity for training of good agricultural practices, including facilitating the business model and market network of agroforestry products.

Author Contributions: Conceptualization and design of the experiments were conducted by D., and K.A.H., who performed the experiments. D and T.O.V analyzed the data and wrote the paper. D, T.O.V, and K.A.H., are the main contributors of the paper, and the others are member contributors. All authors have read and agreed to the published version of the manuscript.

Conflicts of Interest: The authors declare no conflict of interest

Acknowldegement: The authors would like to express heartfelt thanks to the farmers in Tapos and Jagabaya Village who took part in focus group discussions and informant interviews or respondent survey in our research. We would like to express our special gratitude to the field officers in Parungpanjang, including Mr. Adim, Mr. Muhammad, and Mr. Maman, and Dian Anshar for English editing. This paper is one of the joint outputs of Pusat Unggulan Iptek (PUI) between the Center for Political Studies, Indonesian Institute of Sciences and Forest Tree Seed Technology Research \& Development Center (FTSTRDC/BP2TPTH), Ministry of Environment and Forestry of the Republic of Indonesia, 2019.

\section{References}


Angelsen, A., Jagger P., Babigumira, R., Belcher, B., Hogarth, N.J., Bauch, S., Borner, J., Smith-hall, C., Wuder. S. (2014). Environmental Income and Rural Livelihoods: A Global-Comparative Analysis. World Development, 64, S12-S28. https://doi.org/10.1016/j.worlddev.2014.03.006

Baliton, R.S., Wulandari, C., , Landicho, L.D., Cabahug, R.E.D., Paelmo, R.F., COMIA, R.A., Visco, R.G., Budiono, P., Herwanti, S., , Rusita, Castillo, A.K.SA. (2017). Ecological Services of Agroforestry Landscapes in Selected Watershed Areas in the Philippines and Indonesia. Biotropia, 24(1), 71 - 84. https://doi.org/10.11598/btb.2017.24.1.621.

Borrella, I., Mataix, C., Galego, R.C. (2015). Smallholder Farmers in the Speciality Coffee Industry: Opportunities, Constraints and the Businesses that are Making it Possible. IDS Bulletin, 46, 2944.

Brown, S.E., Miller, D.C., Ordonez, P.J., Baylis, K. (2018). Evidence for the impacts of agroforestry on agricultural productivity, ecosystem services, and human well-being in high-income countries: a systematic map protocol. Environmental Evidence, 7(24), 1-16. https://doi.org/10.1186/s13750-018-0136-0

Desmiwati. (2016). Studi Tentang Persepsi dan Tingkat Partisipasi Petani Penggarap di Hutan Penelitian Parungpanjang. Jurnal Perbenihan Tanaman Hutan, 4(2) 109-124.

Desmiwati, Pribadi, M.A., Maharani, K.E. (2018). The Social Capital of Labour-Farmer in the Middle of Parungpanjang Research Forest Governance. Jurnal Perbenihan Tanaman Hutan, 6(1), 6183.

Desmiwati, \& Nugraheni, Y.M.M.A. (2018). Pola Agroforestri dan Strategi Nafkah Petani Penggarap Hutan Penelitian Parungpanjang. Prosiding Seminar Nasional Agroforestry, 257-264.

Dewi, K. H., Raharjo, S. N. I., Desmiwati, Hendarto, K. A., Aminah, A., Wisudayati, T. A., Royani, H, Hasibuan, A. D.S., \& Sari, D. R. (2020). Roles and voices of farmers in the "special purpose" forest area in Indonesia: Strengthening gender responsive policy. Asian Journal of Women's Studies, 26(4), 444-465. http://dx.doi.org/10.1080/12259276.2020.1844972

Dwijanti, R., Sutrisno, J., Pujiasmanto, B., Rahayu, E.S. (2018). Community-based State Forest Management (Social Forestry) In Purworejo Regency Of Central Java Indonesia. Advances in Social Sciences Research Journal (ASSRJ), 5, 290-300. http://dx.doi.org/10.14738/assrj.57.4829.

Faße, A., Grote, U. (2013). The economic relevance of sustainable agroforestry practices: An empirical analysis from Tanzania. Ecological Economics, 94, 86-96. https://doi.org/10.1016/j.ecolecon.2013.07.008

Feliciano, D., Ledo, A., Hillier, J., Nayak, D.R. (2018). Which agroforestry options give the greatest soil and above ground carbon benefits in different world regions?.Agriculture, Ecosystems and Environment 254: 117-129. https://doi.org/10.1016/j.agee.2017.11.032

Humphries, S., Holmes, T. P., Kainer, K., Koury, C. G. G., Cruz, E., Rocha, Rd. M. (2012). Are community-based forest enterprises in the tropics financially viable? Case studies from the $\begin{array}{llll}\text { Brazilian Amazon. Ecological 62-73. } & \text { Economics. }\end{array}$ https://doi.org/10.1016/j.ecolecon.2011.10.018

Kamaluddin, A.K., Tamnge, F., Tamrin, M. (2020). Contribution of Agroforestry to the Plant Communities and Community Welfare in Ternate. Advances in Engineering Research, 194, 2325. https://doi.org/10.2991/aer.k.200325.005

Hendarto, K.A., Desmiwati, Danu, Syamsuwida, D., Yuniarti, N., Siregar, N.W., Aminah, A., Nugraheni, Y.M.M.A., Cahyono, D.D.N., Hidayat, A.R. (2020). Farmer's economic perceptions of demonstration plot development of kaliandra (Calliandra calothyrsus Meisner) biomass energy at Parungpanjang research forest: findings from a focus group discussion. IOP Conf. Series: Earth and Environmental Science, 415(012013). https://doi.org/10.1088/17551315/415/1/012013

Malleson, R., Asaha, S., Sunderland, T., Burnham, P., Egoto, M., Obeng-Okrah, K., Ukpe, I., Miles, W. (2008). A methodology for assessing rural livelihood strategies in West/Central Africa: lessons from the field. Ecological and Environmental Anthropology (University of Georgia), 25. 
Marschke, M., Berkes, F. (2005). Local Level Sustainability Planning for Livelihoods: A Cambodian Experience. International Journal of Sustainable Development and World Ecology. 12, 21-33. http://dx.doi.org/10.1080/13504500509469615

Molla, B. (2019). The Role of Agroforestery on House Hold Income of Rural Communities the Case Soddo Zuria Woreda; South Ehiopia. Global Journal of Human Social Science (B), XIX (III).

Mulyono, A., Suriadikusumah, A., Harriyanto, R., Djuwansah, M.R. (2019). Soil Quality under Agroforestry Trees Pattern in Upper Citarum Watershed, Indonesia. Journal of Ecological Engineering, 20(1), 203-213. https://doi.org/10.12911/22998993/93942

Mutonyi, S., Fungo, B. (2011). Patterns of agroforestry practices among small-holder farmers in the Lake Victoria Crescent Zone (LVCAEZ) of Uganda. Research Journal of Appllied Sciences, 6(4), 251-257.

Nuryati, R., Sulistyowati, L., Setiawan, I., Noor, T.I. (2019). Unveil Indonesia Farmers' Welfare Analysis On Integrated Polyculture Agroforestry Farming (IPAF). International Journal of Scientific \& Technology Research, 8 (11), 1982-1989.

Nyaga, J., Barrios, E., Muthuri, C.W., Öborn, I.,, Matiru, V., Sinclair, F.L. (2015). Evaluating factors influencing heterogeneity in agroforestry adoption and practices within smallholder farms in Rift Valley, Kenya. Agriculture, Ecosystems and Environment, 212:106-118. https://doi.org/10.1016/j.agee.2015.06.013

Parhusip, S., Suharti, S., Sukandi, T., Amano, M., Matsumura, N. (2019). Economic Analysis of Local People's Involvement in Community- based Forest Management (CBFM) in Desa Ciomas, Indonesia. Japan Society of Forest Planning. 0 (0), 1-14. https://doi.org/10.20659/jfp.2019.002

Rahman, S.A., Sunderland, T., Roshetko, J.M., Healey, J.R. (2017). Facilitating smallholder tree farming in fragmented tropical landscapes: Challenges and potentials for sustainable land management. Journal of Environmental Management, 198(110e121). https://doi.org/10.1016/j.jenvman.2017.04.047

Ratina, S. (Ed). (2019). 35 KHDTK_Kawasan Hutan dengan Tujuan Khusus Badan Penelitian, Pengembangan dan Inovasi [35 special purpose forest area of Research, Development \& Innovation]. Sekretariat Badan Penelitian, Pengembangan dan Inovasi, Bogor: BLI Press.

Sarstedt, M., Mooi, E. (2014). Regression Analysis. A Concise Guide to Market Research: The Process, Data, and Methods Using IBM SPSS Statistics (193-233). Berlin: Springer.

Shin, S., Soe, K.T., Lee, H., Kim, T.H., Lee, S., Park, M.S. (2020). A Systematic Map of Agroforestry Research Focusing on Ecosystem Services in the Asia-Pacific Region. Forests, 11(368), 1-23. https://doi.org/10.3390/f11040368

Sudaryanto, Veriasa, T.O. (2018). Shade-grown coffee under fruit trees in highland forests as part of an environmental village restoration. E3S Web of Conferences. 74 (09005). https://doi.org/10.1051/e3sconf/20187409005

Suherdi, Amanah, S., \& Muljono, P. (2014). Motivasi petani dalam pengelolaan usaha hutan rakyat Desa Cingambul, Kecamatan Cingambul, Majalengka. Jurnal Penyuluhan, 10(1), 85-93.

Suyadi, Sumardjo, Uchrowi, Z., Tjitropranoto, P. (2019). Factors Affecting Agroforestry Farmers' Capacity Surrounding National Park. Indonesian Journal of Forestry Research, 6(1); 27-41. https://doi.org/10.20886/ijfr.2019.6.1.27-41

Surati. (2014). Analisis Sikap dan Perilaku Masyarakat Terhadap Hutan Penelitian Parungpanjang. Jurnal Penelitian Sosial dan Ekonomi Kehutanan, 11 (4), 339-347.

Suryanto, P., Widiyatno, Prianto, S. D. A., Permadi, D. B., Affianto, A., Adriana. (2013). Compatibility of Private Agroforestry Management and Managing Forest with Community Program in Central Java, Indonesia. Journal of Management and Sustainability. 3(1), 178-185.

Van Chu, T., Quang Thoai, T., Quoc An, C., Minh Toai, P., Camacho, L. D., \& Sam, H. V. (2019). Contribution of forest to rural households' livelihood: evidences from Da river basin in the northwest mountainous region of Vietnam. Forest and Society, 3(2), 235-247. https://doi.org/10.24259/fs.v3i2.7050 
Wulandari, C., Budiono, P., Yuwono, S. B., \& Herwanti, S. (2014). Adoption of agro-forestry patterns and crop systems around Register 19 Forest Park, Lampung Province, Indonesia. Jurnal Manajemen Hutan Tropika, 20(2), 86-93.

Zomer, R.J., Henry Neufeldt, H., Xu, J., Ahrends, A., Bossio, D., Trabucco, A.,, Noordwijk, M.v., Wang, M. (2016). Global Tree Cover and Biomass Carbon on Agricultural Land: The contribution of agroforestry to global and national carbon budgets. Scientific Reports, 6(29987), 1-12. https://doi.org/10.1038/srep29987 